\title{
Investigation of Self-help Groups (SHGs) Effect on Rural Women Empowerment (Hamedan County, Iran)
}

\author{
Homa Soroushmehr \\ MSc in rural development, Tehran University, Iran \\ Tel: 98-918-111-1967Ｅ-mail: soroshmehr@gmail.com
}

Khalil Kalantari \& Hossein Shabanali Fami

Associate professor Department of Agricultural Management and Development

Tehran University, Karaj

Valiollah Sarani

Assistant Professor, University of Zabol, Iran

Received: February 21, 2011

Accepted: March 8, $2011 \quad$ Online Published: December 1, 2011

doi:10.5539/jas.v4n1p1

URL: http://dx.doi.org/10.5539/jas.v4n1p1

\begin{abstract}
Self-help groups (SHGs) have a special role for empowering rural women that provide a critical outlet for building the way for faster, fairer, and more sustainable socioeconomic status for them. On this basis, study investigates the effect of SHGs on rural women empowerment that 260 rural women from Hamedan county (Iran) were selected as sample. Two groups of women were included in the study; Group 1 (in three subgroups of A, B and $\mathrm{C}$; on based of membership years) included women who have participated in a local SHG, group 2 included women who had never participated in a similar group. The study attempts to understand empowerment process as articulated by the rural women themselves, based upon which their characters in respect of comparison two groups and also women in SHGs. Results indicated that women who in SHGs have high mobility, legal knowledge and decision making autonomy, access and control of household budget, but it's not significant difference between groups 1 and 2 in domestic violence indicator, because of widespread domestic violence and suppression by male family members. Also, Comparison of key socio-economic variables indicated there are significant differences among subgroups (A, B and C), on based of membership years in SHGs.
\end{abstract}

Keywords: Self-help groups (SHGs), Empowerment, Rural women

\section{Introduction}

In developing countries, rural women contribute to $65-70 \%$ of the labor in agriculture (World Bank, 2009). They play a vital role in agriculture, daily reproductive tasks and income generating activities, as most of them are illiterate or less educated and unable to attend formal training courses, social or economic services. But, in fact, less value is given to their contributions, and rural women are less likely to realize their capacity to make a life better for themselves, families and communities (Akinsanmi, 2005). The SHGs, play a role as catalysts in this process (Elliott, 1987) through achieving both individual and group/community purposes to reach empowerment (Fetterman, 1996; Rappaport, 1995; Stein, 1997). As individual and group capacities are enhanced, women's empowerment is capable of becoming a political force that challenges and transforms the existing power structure. SHGs can achieve desired results through changes among both individuals and communities so that the eventual transformation of society takes place (Magar, 2003). Indubitably, without attention to psychosocial aspects of rural women, achievement of sustainable co-operations or SHGs will be inaccessible. In order to improve the situation, practical researches for empowering rural women are widely required. Thus, the general aim of this study is to explain the status of social-economic empowerment in members, bring out the SHGs functions that have been developed exclusively through the use of rural women based samples in Iran. The paper is structured as follows: it begins with an overview of the theoretical concepts that will be used in the article: 
empowerment definitions, economic and social indicators of empowerment, type of rural women SHGs; this is followed by a description of the study and methodology; the findings are then presented; followed by the discussion and conclusions.

\subsection{Empowerment}

Over the past two decades the issue of women empowerment has evolved from relative obscurity to a primary concern among the growing community of researchers and policy makers who are interested in the women's economic and social situation (Kabeer, 2005, Narayan, 2002). Women empowerment stands at the confluence of several international movements and human rights fields (Narayan, 2002; Kaler, 2001). It also emerged as a central research subject within the field of gender and development because empowerment brings power (political, economic or social) for women. Such power reinforces women's economic and social development and building capacity for self-determination (World Bank, 2005). Moser (1991) defines women empowerment as: "giving women the right to determine choices in life and to influence the direction of change through the ability to gain control over crucial material and non-material resources". Osirim (2001) suggests that social well-being, self-esteem, and autonomy coupled with the striving for or achievement of economic independence all define empowerment for women. With the addition of a psychological dimension to empowerment, it is clear that a women's sense of identity and self-perception will be important determining factors in whether she considers herself empowered. In reviewing definitions of the term, this is not surprising given the challenges involved into measurement; because an approach to measure and analyze empowerment has to capture dynamic processes and relational changes that are less predictable, less tangible, more contextual, and more difficult to quantify in data collection and analysis (Graham and Pettinato, 2005; Uphoff, 2005).

Frankenberg and Thomas (2001), analyzed data on 5168 couples from decision making modules in Indonesian families, indicators of empowerment (as dependent variables) were the women role in household decision making; findings showed significant associations between education, and social status of family origin in decision making power, as Grasmuck and Espinal (2000) confirmed that both gender ideology and reliance of households on women's income (as independent and intermediary variables) are important to women decision making, while Hashemi (1996) demonstrated that microcredit empowers women (in households and the community sphere: mobility, economic security, decision making power, participation in public protests and political campaigning) by giving them greater economic value to their families. Jejeebhoy (2000) established that woman's and household's characteristics (e.g. education; participation in waged work, dowry size, spousal difference and household economic status), measured in a variety of ways, associate with economic decision making (e.g. having major say in purchase of jewelry as dependent variable); While Malhotra and Mather (1997) showed that work for pay and education increase decision making inputs in financial, but not social and organization matters in the household. In the community level, Mason (1998) found that social context in terms of gender and family, friends systems has indirect and direct effects on women's economic power. But according to the Mayoux (2001) findings, using existing forms of social networks (majority formal forms) to channel microcredit, limits benefits to women, especially the poorest women.

\subsection{Indicators of empowerment}

Implicit in the use of various indicators for measurement of empowerment is that they have independent influences even if they are adjusted for one another. The reason for this, is that each indicators of women empowerment can be thought to relate to a specific aspect of social, economic and psychology variables. In view of fact, the meaning of any empowerment indicator will always depend on its inter-relationships with other variables. It is also true that a single indicator is not usually sufficient to measure even a specific dimension of empowerment (Kishor, 2000; Estudillo et al. 2001).

Decision making, for instance, may indicate access to resources and control over them related microcredit network (formal or informal) in community and an enabling environment that promotes women's autonomy behavior. Mobility may relate to access to social and economical services and on the other hand may best relate to self-confidence in individual aspects. Research appears to support this view, for example, Kabeer (2001) showed that decision to access loans process, enhance sense of self worth, access to loans process, increase in perceived economic contribution, and decisions about loan use/repayment process, enhance mobility in the public domain and political participation. It's obvious that successive increase in economic empowerment status, regardless of how it is measured, lead to increasingly improved psychosocial status such that the association is more or less linear. Magar (2003), for instance, posed that promoting level of women empowerment by NGOs approaches, became them more agent in life and reduce physical and emotional abuse against them. 
Three direct measures are important for measuring or tracking empowerment: 1. Exists an opportunity to make a choice; 2. A person or group takes the opportunity to choose and 3. Desired result brings out the choice (World Bank, 2005). In this study, information gathered on (a) whether opportunities for economical enhancement exist, such as whether SHGs, grassroots are made; and if so, (b) whether women attempt to involve; and (c) whether they actually use this opportunity to follow their desire volition. To take the loan, especially rural women, exist an institute for them and their ability to take loan is important, if an institute does not physically exist within walking distance, or they didn't have their conditions, rural women have no opportunity. For example a rural woman who wants to take the loan, if a financial institute does not physically exist within walking distance, she has no option, like all villages in this study. Additionally, according to business law in Iran, if a person doesn't have formal work she doesn't have enough qualify for take the loan from institute.

\subsection{Self Help Group}

The SHGs discussed in this paper, were based on an innovative and informal group-based system of lending and saving groups consist of women at the local neighborhoods level, who save money and make small loans to each other within their group. The women invested the money in small income-generating activities, and reliably repaid their loans in to each other. In these groups Women, who demonstrate exceptional capacity and inclination to seek further economic opportunities beyond thrift, joining together (similar to entrepreneurial women). These groups, developed financial management norms covering the loan sanction procedure, repayment schedule without any rates.

Generally a self-help group may consist of 10 to 20 persons. The principle requirement is for a member to know the group's objectives, then to be able to invest 5000 toman (note 1) a month. This self-help group proposes a production job such as dolls, candles making, ready-made clothing, bread, pickle and confection making. Once the job is approved by the group, one third of financing sources are matched together; micro financing by the participants themselves through a rotating credit association under the leadership of one of them. They have annual elections for leadership posts such as chairperson, treasurer, and secretary. Most groups don't have offices or assets; they operate and meet in members' houses. It is after visiting a member that they can even learn of the problems affecting a colleague.

Women in these groups find out that if they pool their resources together in self-help groups of their own creation, they can radically change their lives and the lives of their families and communities so contribution of women in self-help group has a role as opportunity structure which empowers women economically and socially. These groups have intensified good relationships amongst members, who often view themselves more or less like sisters, so it provides the opportunity for collective women's identification and sharing individual experiences; exchange ideas on women rights, nutrition, family planning, child bearing, and discuss among themselves and about the addiction pandemic in their rural. In Hamedan rural area, youth addiction is a serious problem. Women suffer from this problem. Their husbands get women's money and beat them and their children. In SHGs women talk about how they can overcome with this problem and moreover, take their children healthy. They also seek help for their husband to help them for giving up their addiction. During working, women shared stories of how they had managed a better relationship with their husband, his family, children, and how spend their income economically. For illustration, one sample of these can be explained about inherit law in rural society. In rural areas of Hamedan country, taking inheritance by women are not common and rural customs intensified it, but since these groups has been formed and rural women have been participated in family budget, their education and awareness of their rights were improved, gradually this custom changed and rural women could prove themselves in the society and taking of inheritance by them became common.

\section{Materials and methods}

\subsection{Case study}

This study has been conducted in Hamedan county, where women population is 846,430 persons, which is the highest proportion of all women in this province, (93.5\%) have low socioeconomic status (Planning \& Budgeting Organization, 2001). Because of this reason, rural women of Hamedan county was chosen as the study area.

\subsection{Sampling method}

All the villages (96 villages) in Hamedan county were ranked from the one with the SHGs exist, included 56 villages (group 1); to the one with it's not existed (group 2), included 40 villages. Depending on years of SHGs formation, the villages which had SHGs, (group 1), were divided into three subgroups: A, B and C. Subgroup A included women in five villages with less than three years formation of SHG, subgroup B consist of women in eight villages which had formed SHG between 4-6 years, and subgroup C consist of women in three villages 
which formed SHG more than 7 years (table 1). In total, 10 villages were selected of 40 villages, and 16 villages were selected of 56 villages. Thereupon, the study was implemented in total 26 preselected villages. Ten female interviewees from each of the 26 villages were selected using random sampling. Thus, the study covered in total 260 women interviewees.

\subsection{Questionnaire structure}

Data were collected through face-to-face interviews with the women, usually at their homes, based on a structured questionnaire. The questionnaire was based on the published literature on related topics including also previous experience in the field from related projects. The list of empowerment indicators evaluated was assembled and adjusted from a previous study (Malhotra et al., 2002). Besides closed questions, free space for comments or alternative answers was also included.

Before the survey, the questionnaire was tested in a group of scientific board members of the Department of Agricultural Management and Development of Tehran University and a Tehran University Rural Development department scientific board member. It was modified according to comments and suggestions of the early rural women. Cronbach's alpha coefficient, a measure of internal consistency, was used to estimate the reliability of the survey questionnaire. This coefficient ranges in value from 0 to 1 and it describes the reliability of factors extracted from dichotomous or multi-point formatted questionnaires or scales. Cronbach's alpha coefficient was found to be 0.86 for importance and 0.88 for competence, indicating an acceptable level of reliability (Nunnally, 1978).

Women gave oral consent to participate in the study after they heard a brief explanation of the study's objectives. Because the majority of the data is qualitative, they are converted to quantitative data by using statistical scaling method. Women divided into two independent groups: members of SHG and none. Each woman is coded dichotomously with a score of 0 indicating non-member of SHG and 1 indicating member of it. Members of SHG also divided in three subgroups on based of membership experiences (table 1).

\section{Results and discussion}

\subsection{Individual Characteristics of the responses}

In order to obtain an insight into the composition of the responses 260 women, table (2) shows the distribution of responses according to personal features. It shows that respectively $36 \%, 47 \%$ and $12 \%$ of responses are in the age groups between $15-20,21-30,31-40$ while $4 \%$ is older than $41.95 .7 \%$ of responses are young but approximately $28 \%$ of them are illiterate and $34 \%$ finished primary school (5 years of education). Older women tend to be either illiterate or have a relatively low level of education. The majority of younger women continue to be excluded from schooling, as female children are kept at home for domestic work. The majority of the responses (92\%) are married. The traditional age to get married is low in the study region, because parents want to get rid of their "burden" as soon as possible, thus early marriages are not exceptional. $34 \%$ of women had less than six years differences with their husband and approximately $83 \%$ of them more than 6 years. $83.2 \%$ of women had less than 5 pregnancies, a reason for this apart from the education, having knowledge of family planning during reproductive health class education in rural areas.

\subsection{The socioeconomic indicators distribution}

In following of researchers' conceptualization from empowerment process, it can be categorized as economic and social. The economical measure (table 3 ) is obtained by asking individuals to rate their control of finance resources, women share of earned income and decision making autonomy during their participation in SHG, and for non-participating women during their life after marriage. Response categories included very high, high, middle, fair, very fair and none. These scores have been collected from all women, and they have been converted into total scores. Responses of very high, high and middle are scored as 1 indicator of high empowerment while the other categories are scored 0 , indicator of poor empowerment.

Empowerment process aims to expand women's access to and control over fundamental assets (capital, land, and knowledge); strengthen women's agency, including their decision-making role in community affairs and representation in local institutions; and improve well-being and ease workloads by facilitating access to basic rural services and infrastructures. Thus, in view of empowerment, agency is at the heart of process, and it defined as an actor or group ability to make purposeful choices, but when people have the capacity to choose options, they may not be able to use that agency effectively. Actors need a raised level of consciousness if they are to translate their economic assets into choices that is, to become "agents." Women, in particular, are often locked into a cultural framework in which they perceive their disempowerment to be right and proper (Kabeer, 1999). For instance, if women earn money from her work under grassroots or co-operations (agency), they may 
not be able to expense their money under their will (achievements). The achievement of choice is a measure of how far a person or group is able to achieve the desire outcomes. Thus, economic empowerment measure in the study also, included these items; economic contribution to household, access to household budget, spends money under desire will, and control of household budget.

Access to financial services in rural areas allows women to manage their household cash flows, start new activities and set up small businesses. When poor rural people have higher earnings and safe ways to save their money, as table (3) data shows, women in SHGs can economically contribute to household, access and control to household budget, additionally pay for household purchases and sale and purchase of assets (like jewels). Approximately $50 \%$ of SHGs rural women, can decide to work or not, whereas only $17.2 \%$ of rural women who were not in SHGs, can decided for it. Women decision making in labor and sale in agricultural production were low, in regards of their business were not about agriculture, they expressed "we have not enough confidence to directly involve in men jobs, but we say anything which learns in SHG and extension agriculture classes, like "what kind of disease our farm has and what it's needed". Women have these attribute in their minds, whereas they actively participate in agriculture production like journeyman.

The social measure combined responses to four items representing social SHG function: First, responses were asked their freedom of mobility; second, their legal knowledge; third, role in non-economic decision making and fourth, freedom from violence during their participation in SHG. They have been scores as described above. Descriptive information and distribution for these indicators is provided in table (3). The study that report socioeconomic indicators by grouping the responses with respect to SHG members and none, it turns out that $61.54 \%$ of women have participated in these groups, while approximately $38 \%$ of them have not participated. As the table (3) data shows, women in SHGs have high mobility, legal knowledge and decision making autonomy, access and control of household budget, but in regards of widespread domestic violence and suppression by male family members, there is not high difference between groups, in suffering from domestic violence. Moreover, It shows that women suffer from domestic violence differently; women who were in SHG threat more of getting another wife from their husband, and women who were not in SHG threat more from cutting money from their husband. In view of women, the fact is, domestic violence is not a problem; they accepted it: "when my husband in great rage, it's ok to begin roar and we must endure it".

\subsection{Comparison between two groups of women in $S H G$ and women not in $S H G$}

An independent sample t-test (table 4) was performed to compare between two groups, which is women members in SHG (group 1), and women not participate in SHG (group 2), with regards to their economic and social empowerment indicators respectively. Each of the women indicators between the participant group and the non participant group criteria is statistically significant except for domestic violence. For a better understanding of the effectiveness of SHG, it is useful to examine which women characteristics are particularly supportive or inhibiting to the impact of the SHG. According to results of table (4), there are significant differences among groups about indicators of economic empowerment (economic contribution to household, decision making autonomy, access to household budget, control of household budget and spends money under desire will).Among indicators of social empowerment, there are significant differences in indicators of mobility and legal knowledge only.

\subsection{Comparison socio-economic variables among the three groups of women in $\mathrm{SHG}$}

According to results of table (5), by grouping the women in SHG with respect to membership years, it turns out that $36.7 \%$ of women have 3.1 membership years, the majority $47.3 \%$ of women have 4.9 years and the lowest group have 6.5 years of membership experience. Also, an independent sample F-test (table 5) was performed to compare among subgroups of A, B and C. Women of all subgroups have low levels of education with average education periods 3.7, 3.8, and 2.5 years for subgroup A, subgroup B, and subgroup C, respectively. Comparison of key socio-economic variables indicated significant differences amongst all subgroups in years of membership in SHG, SHG income, loan, and land ownership (table 5). Subgroup C reported the highest loan amount borrowing between members, high income, and saving, from their job but the least membership among the three subgroups. However, no significant differences were found in variables such as age, education and saving amount within groups.

Comparison of economic and social empowerment indicators indicated significant differences among subgroups on each indicator except access to household budget and freedom from violence. In respect of economical indicators, subgroup B showed the highest economic contribution to household and decision making autonomy in their members. Subgroup $\mathrm{C}$ have the most control of household budget additionally their members spends 
money under desire will in comparison with another groups. Respect to social indicators, subgroup B scored the highest mobility and decision making autonomy.

\section{Conclusion and recommendations}

Data of this study provide a view of how the women SHGs' mechanism can influence the economic and social empowerment in Hamedan villages in Iran. Understanding the dynamic processes of change occurred by empowerment, is crucial to better position for faster growth of SHGs and sustained development, which is vital for livelihoods security for millions of women and their families worldwide. All women in this study have off-form activities like dairy production and poultry rearing, but only women in SHGs can transfer their activity into money (additionally their group activities and income), so women in SHG standing in high level of empowerment in comparison of other women. The main reason of this as the main SHG function; mobility, perception legal knowledge that leads to get inherit, although this happen during 3.5 years after group formation in average. Empowerment process does not develop very fast, additionally in isolation, moreover without help of men; inherit law in villages occurred with group function and with husband help.

Growth and development in countries simply cannot be done while ignoring women, who are the major actors. Recognizing the role of SHGs in empowering rural women, key development organizations have engaged in a process of mainstreaming gender into rural development. This study suggests that using empowerment policy developers should address gender issues as the role of women is important for policies aimed at (1) supporting of women's movement and (2) with respect the education rising awareness of women and men in gender issues. Women are very interested in education and improving their personal skills and competencies and this offers scope for policy developers to devise new education programs to help women improve the level of off-farm and business technical and economical skills they need. As the women groups operate at their own pace and take up new activities at their own demand, it prevents them rapidly coming to get benefits. To accelerate the empowerment process important for policy developers because they may to plan advanced business programs and training courses for SHGs or their leaders. Establishing and training multidisciplinary teams of district-level extension and line-level agency staff can improve support to producers, particularly if they are organized into effective groups. For instance, Proshika, a Bengali NGO, offers an integrated package of assistance to women's poultry groups by training women as par veterinarians through group courses. The groups are provided with loans and technical extension services, and a compensation farm has been established to compensate for losses and therefore minimize risk for project participants. The project has caused the average weekly incomes of participating households to rise by 31 percent after becoming members (World Bank, 2009).

When women have an income, substantial evidence indicates that the income is more likely to be spent on food and children's needs. Women are generally responsible for food selection and preparation and for the care and feeding of children. Women are the key to food security for their households (Quisumbing et al., 1995). Women disempowerment decrease family health, nutrition, even agricultural productivity and efficiency and in so doing, undermine development programs and investments. Failure to recognize the training needs of women is costly because it results in misguided projects and programs, forgone agricultural output and incomes, and food and nutrition insecurity. The policy maker should be take into account the role of women's SHGs in rural development and to increase concerted efforts to enable them to move beyond production for subsistence and into higher-value, market-oriented production.

Community improvement has occurred in the way that gender issues and women's empowerment are addressed throughout the developments project, starting with project design (World Bank, 2006). However, studies have highlighted the need to ensure greater continuity between design and implementation to integrate women's SHGs more fully into mainstream development activities (GENRD, 2007; IFAD, 2003). It's necessary for policy makers to promote an enabling environment through policy and institutional reform (decentralization, sector policies, and so on), strengthen local governance relationships (including forging linkages between community based organizations and local governments), enable community-level organizations to play a broader role in the design and implementation of policies and programs affecting women livelihoods, and enhance the impact of SHGs activities on the local economy at the community level.

Overall, the women in SHGs have high mobility, legal knowledge and decision making autonomy, access and control of household budget, but in regards of widespread domestic violence and suppression by male family members, there is not high difference between groups 1 and 2. In view of rural women it's not a problem, or at least not a serious problem. This attribute as a chain inherits daughters from ancient grandmothers to mothers to daughters, like a vicious circle. The lack of access to knowledge and information, exclude women from their rights within the family and within the community. Women should be learning that domestic violence is an 
infringement of their rights and that they are entitled to seek help or redress. The capacity of these women to choose a different way of living requires a change in their psychological assets which, in this case, is prerequisite to a change in the social institutions governing the right of a husband to beat his wife. It needs to involve policy developers to move rural communities toward gender equality ideals. They should initially focus on family's violence-stories and how they are satisfied to change their minds to ultimately improve human development. This provides an opportunity for policy developers to cooperate with women in creating more supportive communities for them in the long-term.

\section{Acknowledgement}

We are thankful to the participation of 260 women in Hamedan county in this study. We are grateful to one anonymous reviewer for additional comments. Remaining errors are ours.

\section{References}

Akinsanmi, A. (2005). Working Under Constraint: Women, Poverty and Productivity. Women and Environments International, 66/67: 17-18.

Elliott, Charles. (1987). Some aspects of relations between the north and south in the NGO sector. World development. ( pp. 57-68). http://dx.doi.org/10.1016/0305-750X(87)90143-4

Estudillo, J., Agnes, P., Quisumbing, R,. \& Keijiro O. (2001). Gender differences in land inheritance, schooling and lifetime income: Evidence from the rural Philippines. Journal of Development Studies, 37(4):23-48. http://dx.doi.org/10.1080/00220380412331322031

Fetterman, D. M. (1996). Empowerment evaluation: An introduction to theory and practice. In D.M. Fetterman, S.J. Kaftarian, \& A. Wandersman (Eds.), Empowerment evaluation: Knowledge and tools for self-assessment and accountability (pp. 3-46). Thousand Oaks: Sage Publications.

Frankenberg, E., \& Duncan T. (2001). Measuring Power. Food Consumption and Nutrition Division Discussion Paper No. 113. Washington DC: International Food Policy Research Institute.

Gender and Rural Development Thematic Group (GENRD). (2007). FY07 Gender Portfolio Review. World Bank, Washington, DC.

Graham, C., \& Pettinato, S. (2005). Subjective Well-Being and Objective Measures: Insecurity and Inequality in Emerging Markets. In Measuring Empowerment: Cross-Disciplinary Perspectives, ed. D. Narayan, 141-75, Washington, DC: World Bank. http://dx.doi.org/10.1177/089124300014002002

Grasmuck, S., \& Espinal R. (2000). Market success or female autonomy? Income, ideology, and empowerment among microentrepreneurs in the Dominican Republic. Gender and Society, 14(2):231-255.

Hashemi, S. M., Sidney Ruth, S., \& Riley. (1996). Rural credit programs and women's empowerment in Bangladesh. World Development, 24(4):635-653. http://dx.doi.org/10.1016/0305-750X(95)00159-A

International Fund for Agricultural Development (IFAD). (2003). Mainstreaming a Gender Perspective in IFAD's Operations: Plan of Action 2003-2006. IFAD, Rome.

Jejeebhoy, S. (2000). Women's autonomy in rural India: Its dimensions, determinants, and the influence of context. In Women's Empowerment and Demographic Processes: Moving Beyond Cairo. Harriet Presser and Gita Sen, eds. New York: Oxford University Press.

Kabeer, N. (2005). Is Microfinance a 'Magic Bullet' for. Women's Empowerment: Analysis of Findings from. South Asia. Economic and Political Weekly, 40(44): 4709-4718.

Kabeer, N. (1999). Resources, Agency, Achievements: Reflections on the Measurement of Women's Empowerment. Development and Change, 30: 435-64. http://dx.doi.org/10.1111/1467-7660.00125

Kabeer, N. (2001). Reflections on the measurement of women's empowerment. In Discussing Women's Empowerment-Theory and Practice. Sida Studies. No. 3. NovumGrafiska AB: Stockholm.

Kaler, A. (2001). It's Some Kind of Women's Empowerment: The Ambiguity of the Female Condom as a Marker of Female Empowerment. Social Science and Medicine, 52, 783-796. http://dx.doi.org/10.1016/S0277-9536(00)00185-4

Kishor, S. (2000). Women's contraceptive use in Egypt: What do direct measures of empowerment tell us? Paper prepared for presentation at the annual meeting of the Population Association of America, March 23-25, 2000, Los Angeles, California. 
Magar, V. (2003). Empowerment Approaches To Gender-Based Violence: Women's CourtsIn Delhi Slums. Women's Studies International Forum, Vol. 26, No. $^{2}$ 6, pp. 509 - 523. http://dx.doi.org/10.1016/j.wsif.2003.09.006

Malhotra, A. \& Mather. M. (1997). Do schooling and work empower women in developing countries? Gender and domestic decisions in Sri Lanka. Sociological Forum, 12(4): 599-630. http://dx.doi.org/10.1023/A:1022126824127

Malhotra, A., S. R. Schuler, \& C. Boender. (2002). Measuring Women's Empowerment as a Variable in International Development. Gender and Development Group, World Bank, Washington, DC.

Mason, K. (1998). Wives' economic decision-making power in the family: Five Asian countries. Pp. 105-133 in The Changing Family in Comparative Perspective: Asia and the United States. Karen Oppenheim Mason, ed. Honolulu: East-West Center.

Mayoux, L. (2001). Tackling the down side: Social capital, women's empowerment and micro-finance in Cameroon. Development and Change, 32:435-464. http://dx.doi.org/10.1111/1467-7660.00212

Moser, C. (1991). Gender planning in the third world: Meeting practical and strategic needs. In R. Grant \& K. Newland (Eds.), Gender and international relations. Bloomington: University of Indiana Press.

Narayan, D., ed. (2002). Empowerment and Poverty Reduction: A Sourcebook. Washington, DC: World Bank.

Nunnally, J.C. (1978). Psychometric Theory. McGraw-Hill Company, New York.

Osirim, J.M. (2001). Making good on commitments to Grassroots Women: NGO's And Empowerment for women In Contemporary Zimbawe. Women's Studies International Forum, Vol. 24, No. 2, pp 167-180. http://dx.doi.org/10.1016/S0277-5395(01)00154-6

Planning \& Budgeting Organizationof Iran, Hamedan county, (2001). Socioeconomic status of Hamedan women. In perian.

Quisumbing, A.R., L.R. Brown, Hilary S. Feldstein, L. Haddad, and Ch. Peña. (1995). Women: The Key to Food Security. Food Policy Statement 21. Washington, DC: International Food Policy Research Institute.

Rappaport, J. (1995). Empowerment meets narrative: Listening to stories and creating settings. American Journal of Community Psychology, 23(5), 795- 807. http://dx.doi.org/10.1007/BF02506992

Stein, J. (1997). Empowerment and women's health: Theory, methods and practice. London: Zed Books.

Uphoff, N. (2005). Analytic Issues in Measuring Empowerment at the Community and Local Levels. In Measuring Empowerment: Cross-Disciplinary Perspectives, ed. D. Narayan, 219-46, Washington, DC: World Bank.

World Bank. (2005). Empowerment in Practice From Analysis to Implementation. Ruth Alsop, Mette Frost, Bertelsen Jeremy, Holland16031-IN. South Asia Environment and Social Unit, World Bank, Washington, DC.

World Bank. (2006). Implementing the Bank's Gender Mainstreaming Strategy: Annual Monitoring Report for FY04 and FY05. World Bank, Washington, DC.

World Bank. (2009). Gender in agriculture. World Bank, Food and Agriculture Organization, and International Fund for Agricultural Development. World Bank1818 H Street, NW Washington, DC.

\section{Note}

Note 1: 1 US dollar $=959.573$ Iranian Toman. 
Table 1. Grouping responses

\begin{tabular}{|c|c|c|c|c|}
\hline $\begin{array}{l}\text { Responses } \\
\text { groups }\end{array}$ & $\begin{array}{l}\text { Years of } \\
\text { membership }\end{array}$ & $\begin{array}{l}\% \text { of } \\
\text { responses }\end{array}$ & $\begin{array}{ll}\begin{array}{l}\text { Number } \\
\text { responses }\end{array} & \text { of } \\
\end{array}$ & Names of villages \\
\hline \multicolumn{5}{|l|}{ Group 1} \\
\hline Subgroup A & $0-3$ & 19.5 & 50 & - Sorkhabad, Abaru, Dehpeiaz,Mahbar, Kurkahriz \\
\hline Subgroup B & $4-6$ & 31 & 80 & $\begin{array}{l}\text { - Yekane, Dehdelian, Tafrijan, Shirabad, } \\
\text { Oyouk, Saerdarre, Marouf, Gholikandi }\end{array}$ \\
\hline Subgroup C & $7+$ & 11 & 30 & - Sheverin, Amzajerd, Arablu \\
\hline Group 2 & - & 38.5 & 100 & $\begin{array}{l}\text { - Kozare, Khomajin, Dizaj, Hizaj, Razaj, Idlu, Aghdagh, } \\
\text { Hassan abad, Haji maghsud, Sabzabad }\end{array}$ \\
\hline
\end{tabular}

Table 2. Personal features of women

\begin{tabular}{|l|c|c|}
\hline Features & frequency & $\%$ \\
\hline Age groups & & \\
\hline $15-20$ & 94 & 36.7 \\
\hline $21-30$ & 125 & 47.3 \\
\hline $31-40$ & 30 & 11.7 \\
\hline $41+$ & 11 & 4.3 \\
\hline Education levels & & \\
\hline 1. Illiterate & 72 & 28.1 \\
\hline 2. Literate (not primary school) & 27 & 10.5 \\
\hline 3. Primary school & 92 & 34 \\
\hline 4. Secondary school & 41 & 16 \\
\hline 5. High school & 19 & 7.4 \\
\hline 6. University (2 years) & 10 & 3.9 \\
\hline Marital status & & \\
\hline 1. Single & 10 & 3.7 \\
\hline 2. Widow & 12 & 4.5 \\
\hline 3. Married & 238 & 91.8 \\
\hline Number of pregnancy & & \\
\hline $0-2$ & 66 & 25.8 \\
\hline $3-5$ & 151 & 57.4 \\
\hline $6-8$ & 34 & 13.3 \\
\hline $9+$ & 9 & 3.5 \\
\hline Age differences between spouses & & \\
\hline 6< & 87 & 34 \\
\hline $6-10$ & 130 & 49.2 \\
\hline $10+$ & 43 & 8.16 \\
\hline & & \\
\hline
\end{tabular}


Table 3. Study socioeconomic indicators distribution

\begin{tabular}{|c|c|c|c|c|}
\hline \multirow{2}{*}{ variables } & \multicolumn{2}{|c|}{ Participants } & \multicolumn{2}{|c|}{ Non-participants } \\
\hline & $\%$ high & $\%$ low & $\%$ high & $\%$ low \\
\hline \multicolumn{5}{|l|}{ Economic empowerment } \\
\hline Economic contribution to household & 59.2 & 40.8 & 32.3 & 67.7 \\
\hline Access to household budget & 54.8 & 45.2 & 32.3 & 67.7 \\
\hline Control of household budget & 63.6 & 36.4 & 24.8 & 75.2 \\
\hline Spends money under desire will & 76.4 & 23.6 & 29.3 & 70.7 \\
\hline \multicolumn{5}{|l|}{ Decision making autonomy } \\
\hline Household purchases & 85.9 & 14.1 & 63.7 & 36.3 \\
\hline Labor and sale in agricultural production & 11.1 & 88.9 & 6.4 & 93.6 \\
\hline Whether wife works & 50.5 & 49.5 & 17.2 & 82.8 \\
\hline Sale and purchase of assets & 24.2 & 75.8 & 4.5 & 95.5 \\
\hline \multicolumn{5}{|l|}{ Social empowerment } \\
\hline \multicolumn{5}{|l|}{ Mobility } \\
\hline Health center & 82.8 & 17.2 & 73.9 & 26.1 \\
\hline Journey in City & 82.2 & 17.8 & 44.4 & 55.6 \\
\hline Purchase from City & 77.7 & 22.3 & 57.6 & 42.4 \\
\hline Sale production in city bazaar & 91.1 & 8.9 & 30.3 & 69.7 \\
\hline See family \& friends & 59.2 & 40.8 & 33.3 & 66.7 \\
\hline Government organizations & 84.1 & 15.9 & 39.4 & 60.6 \\
\hline \multicolumn{5}{|l|}{ Legal knowledge } \\
\hline Inherit law $^{\mathrm{a}}$ & 81.5 & 18.5 & 8.1 & 91.9 \\
\hline Divorce law & 87.9 & 12.1 & 7.1 & 92.9 \\
\hline \multicolumn{5}{|l|}{ Decision making autonomy } \\
\hline Wherelwhen to go journey & 77.7 & 22.3 & 46.5 & 53.5 \\
\hline Having children & 89.2 & 10.8 & 7.1 & 92.9 \\
\hline Number of children & 81.5 & 18.5 & 35.4 & 64.6 \\
\hline Children's education & 59.9 & 40.1 & 36.4 & 63.6 \\
\hline Children marriage & 70.7 & 29.3 & 36.4 & 63.6 \\
\hline \multicolumn{5}{|l|}{ Freedom from violence } \\
\hline Oral threat & 8.9 & 91.1 & 6.1 & 93.9 \\
\hline Physical threat & 26.1 & 73.9 & 17.2 & 82.8 \\
\hline Threat to abandon family & 17.8 & 82.2 & 34.3 & 65.7 \\
\hline Threat to divorce & 14 & 86 & 12.1 & 87.9 \\
\hline Threat to cut money & 51.6 & 48.4 & 13.1 & 86.9 \\
\hline Threat to get another wife & 34.4 & 65.6 & 11.1 & 88.9 \\
\hline
\end{tabular}

a In SHGs has been explaining that in law, women can take their inheritance, however, it's half in compare of men. But rural women did not take even this half inheritance. In fact rural women have no awareness about their inherit law before these groups formed. 
Table 4. Independent sample t-test between women in SHG and women not in SHG

\begin{tabular}{|c|c|c|c|c|c|c|c|}
\hline \multirow[t]{2}{*}{ Indicators } & \multirow[t]{2}{*}{ Groups } & \multirow[t]{2}{*}{ Mean } & \multirow[t]{2}{*}{$t$} & \multirow[t]{2}{*}{$p$-Value } & \multirow[t]{2}{*}{ Std. deviation } & \multicolumn{2}{|c|}{$\begin{array}{l}95 \% \text { Confidence interval } \\
\text { of the difference }\end{array}$} \\
\hline & & & & & & Lower & Upper \\
\hline \multicolumn{8}{|l|}{ Economic empowerment } \\
\hline \multirow[t]{2}{*}{ Economic contribution to household } & Group1 & 12.19 & 6.86 & .000 & 7.03 & 10.11 & 5.60 \\
\hline & Group2 & 20.05 & 6.20 & .000 & 11.29 & 10.36 & 5.35 \\
\hline \multirow[t]{2}{*}{ Decision making autonomy } & Group1 & 20.84 & 7.88 & .000 & 6.80 & 9.53 & 5.72 \\
\hline & Group2 & 28.47 & 7.48 & .000 & 8.58 & 9.63 & 5.61 \\
\hline \multirow[t]{2}{*}{ Access to household budget } & Group1 & 11.97 & 10.87 & .000 & 4.08 & 6.69 & 4.64 \\
\hline & Group2 & 17.64 & 10.90 & .000 & 4.03 & 6.69 & 4.64 \\
\hline \multirow[t]{2}{*}{ Control of household budget } & Group1 & 12.95 & 10.26 & .000 & 3.72 & 6.02 & 4.08 \\
\hline & Group2 & 18.01 & 10.09 & .000 & 4.01 & 6.04 & 4.06 \\
\hline \multirow[t]{2}{*}{ Spends money under desire will } & Group1 & 11.15 & 9.05 & .000 & 5.09 & 6.44 & 4.14 \\
\hline & Group2 & 16.44 & 9.18 & .000 & 3.52 & 6.35 & 4.22 \\
\hline \multicolumn{8}{|l|}{ Social empowerment } \\
\hline \multirow[t]{2}{*}{ Mobility } & Group1 & 14.14 & 7.52 & .000 & 5.68 & 7.60 & 4.44 \\
\hline & Group2 & 20.17 & 7.17 & .000 & 7.03 & 7.68 & 4.36 \\
\hline \multirow[t]{2}{*}{ Legal knowledge } & Group1 & 41.47 & 10.60 & .000 & 9.02 & 16.24 & 11.15 \\
\hline & Group2 & 55.17 & 10.03 & .000 & 11.53 & 16.39 & 11.00 \\
\hline \multirow[t]{2}{*}{ Decision making autonomy } & Group1 & 4.61 & 6.20 & .000 & 2.29 & 2.53 & 1.35 \\
\hline & Group2 & 6.55 & 6.45 & .000 & 2.38 & 2.53 & 1.34 \\
\hline \multirow[t]{2}{*}{ Freedom from violence } & Group1 & 45.73 & 0.84 & Ns & 119.39 & 47.54 & 18.92 \\
\hline & Group2 & 60.04 & 0.80 & Ns & 148.75 & 49.29 & 20.68 \\
\hline
\end{tabular}

Table 5. Comparison of socio-economic variables among the three subgroups of women in SHG

\begin{tabular}{|l|c|c|c|c|}
\hline Participation group & Subgroup A & Subgroup B & Subgroup C & $F$ test \\
\hline \% of responses & 36.7 & 47.3 & 16.0 & - \\
\hline Membership experience & 2.1 & 4.9 & 6.5 & $2.164^{*}$ \\
\hline Age & 28.3 & 38.1 & 52 & $0.306 \mathrm{~ns}^{\mathrm{b}}$ \\
\hline Education (years) & 3.7 & 3.8 & 2.5 & $0.533 \mathrm{~ns}$ \\
\hline Income (Toman ${ }^{\mathrm{a}}$ ) & 2,859 & 28,612 & 102,500 & $467.4^{* *}$ \\
\hline Saving (Toman) & 170,125 & 175,612 & 223,557 & $0.177 \mathrm{~ns}$ \\
\hline Loan (Toman) & 7,720 & 14,612 & 50,076 & $8.53^{* *}$ \\
\hline Members land ownership (ha) & 1.3 & 2.73 & 5.17 & $13.40^{* *}$ \\
\hline Economic empowerment & & & & \\
\hline Economic contribution to household & 19.20 & 21.60 & 18.09 & $5.63^{*}$ \\
\hline Decision making autonomy & 19.95 & 28.63 & 24.17 & $24.93^{* *}$ \\
\hline Access to household budget & 19.15 & 20.53 & 30.83 & $1.42 \mathrm{~ns}$ \\
\hline Control of household budget & 10.01 & 13.61 & 15.83 & $22.63^{* *}$ \\
\hline Spends money under desire will & 1.32 & 1.77 & 1.37 & $20.57^{* *}$ \\
\hline Social empowerment & & & & \\
\hline Mobility & 14.91 & 19.65 & 14.44 & $13.48^{* *}$ \\
\hline Legal knowledge & 72.75 & 68.30 & 61.21 & $0.17 \mathrm{~ns}^{* * \mid}$ \\
\hline Decision making autonomy & 4.59 & 6.66 & 4.94 & $17.21^{* *}$ \\
\hline Freedom from violence & 44.22 & 32.81 & 36.75 & $0.22 \mathrm{~ns}$ \\
\hline
\end{tabular}

*significant at $\mathrm{P}<0.05$. ${ }^{* *}$ significant at $\mathrm{P}<0.01$.

${ }^{\mathrm{a}} 1$ US dollar $=959.573$ Iranian Toman. ${ }^{\mathrm{b}}$ Non significant. ${ }^{\mathrm{c}}$ it becomes from inherit. 